\begin{tabular}{|c|c|c|}
\hline C & \multicolumn{2}{|c|}{ Case Rep Gastroenterol 2015;9:327-334 } \\
\hline Gastroenterology & $\begin{array}{l}\text { DOI: } 10.1159 / 000441381 \\
\text { Publisnea Onine: Uctober 21, } 2015\end{array}$ & $\begin{array}{l}\text { (c) } 2015 \text { The Author(s) } \\
\text { Published by S. Karger AG, Basel } \\
1662-0631 / 15 / 0093-0327 \$ 39.50 / 0 \\
\text { www.karger.com/crg }\end{array}$ \\
\hline
\end{tabular}

This article is licensed under the Creative Commons Attribution-NonCommercial 4.0 International License (CC BY-NC) (http://www.karger.com/Services/OpenAccessLicense). Usage and distribution for commercial purposes requires written permission.

\title{
Large-Cell Neuroendocrine Carcinoma of the Esophagus: A Case from Saudi Arabia
}

\author{
Hadi Kuriry $^{a} \quad$ Abdul Monem Swied $^{b}$ \\ ${ }^{a}$ King Abdulaziz Medical City and ${ }^{b}$ King Saud bin Abdulaziz University for Health Science, \\ Riyadh, Saudi Arabia
}

\section{Key Words}

Neuroendocrine carcinoma · Esophageal tumor · Large cell

\begin{abstract}
Neuroendocrine carcinomas of the esophagus are very rare, and the majority are high grade (poorly differentiated). They occur most frequently in males in their sixth and seventh decades of life. There have been no concrete data published on clinical features or on prognosis. We report a case of large-cell neuroendocrine carcinoma of the esophagus in a 66-yearold Saudi female with progressive dysphagia and weight loss. Upper endoscopy revealed an esophageal ulcerated mass.

(C) 2015 The Author(s)

Published by S. Karger AG, Basel
\end{abstract}

\section{Introduction}

The term 'neuroendocrine' reflects the origin of endocrine cells from the embryonic neural crest [1]. Neuroendocrine cells are characterized by their ability to produce and secrete different peptides and neuroamines [2]. They aggregate in classical endocrine glands (e.g. hypothalamus and the pituitary gland) or in the diffuse neuroendocrine system distributed throughout the body, such as the gastrointestinal tract and lungs [3].

Gastroenteropancreatic neuroendocrine neoplasms (GEP-NENs) are a heterogeneous group of neoplasms defined as malignant transformation of neuroendocrine cells in the diffuse neuroendocrine system that regulates secretion, absorption and motility of the gastrointestinal tract. The incidence of GEP-NENs continues to exhibit a persistent increase; the most recent epidemiological study from the US Surveillance shows that the overall incidence of GEP-NENs increased from 1 to 3.65 cases per 100,000 [4]. This may attributed to the im-

\section{KARGER 125}


Kuriry and Swied: Large-Cell Neuroendocrine Carcinoma of the Esophagus: A Case from Saudi Arabia

provement in diagnostic techniques and increased clinical awareness. A genetic etiology of GEP-NENs has been well documented in around 5-10\% of cases as part of hereditary syndromes such as multiple endocrine neoplasia type 1, von Hippel-Lindau syndrome, neurofibromatosis 1 or tuberous sclerosis syndrome [5, 6]. These tumors commonly present with a wide spectrum of clinical manifestations according to site of origin and biological behavior. They can present with abdominal pain, weight loss, obstructive jaundice and intestinal obstruction. Moreover, the symptoms related to hormone secretion include flushing, diarrhea, wheezing, hypoglycemia, cardiovascular and peptic ulcers disease [7].

The diagnosis is based on histological features, including tumor differentiation and grade, in addition to immunohistochemical stains for general endocrine markers, including chromogranins, synaptophysin and neuron-specific enolase. There is no ideal serological neuroendocrine tumor marker. Tumor markers such as chromogranin A, pancreatic polypeptide, serum neuron-specific enolase and subunit of glycoprotein hormones have been used. Chromogranin A is the best available biomarker for the diagnosis of NENs. The sensitivity and specificity for detection of NENs range between 70 and $100 \%$. It is useful for staging, prognosis and follow-up, since the serum concentration correlates with the tumor mass [8]. In the presence of symptoms or syndrome suspicious of functional NENs, biochemical testing for peptide hypersecretion should be ordered, e.g. gastrin level for patients with Zollinger-Ellison syndrome or insulin for hypoglycemic syndromes [9].

Imaging studies are an important tool in NEN workup; abdominal ultrasound, computed tomography and magnetic resonance imaging have a high sensitivity and specificity in detecting many types of primary NENs. Endoscopic ultrasound plays an important role in obtaining histopathological samples and in tumor staging. Functional imaging such as ${ }^{111} \mathrm{In}-$ pentetreotide (OctreoScan) or 123I-metaiodobenzylguanidine (MIBG) plays a critical role in the diagnosis and in establishing the eligibility for therapy. Combining functional imaging with computed tomography or magnetic resonance imaging is superior for staging and detection of primary tumors of undetermined location [10].

GEP-NENs can be classified according to the site of embryologic origin (foregut, midgut and hindgut), grade, differentiation or the hormones produced. The grade refers to the biological aggressiveness of the neoplasm which is defined by the number of mitoses per 10 high-power microscopic fields or per $2 \mathrm{~mm}^{2}$ (mitotic rate), or as the percentage of tumor cells that immunolabel for the Ki-67 antigen (Ki-67 index). While the differentiation refers to the extent to which the neoplastic cells resemble their non-neoplastic counterparts [11], in 2010, the World Health Organization proposed the most widely accepted classification: (1) neuroendocrine tumor grade 1 (G1), (2) neuroendocrine tumor grade 2 (G2), (3) neuroendocrine carcinoma (NEC), grade 3 (G3), and (4) mixed adenoneuroendocrine carcinoma [12]. Also, NENs are divided into well-differentiated and poorly differentiated (table 1). In general, well-differentiated NENs are more common than poorly differentiated ones. However, esophagus and colon NENs are more often poorly differentiated [13].

GEP-NENs are staged according to the primary tumor (T), lymph node involvement $(\mathrm{N})$ and distant metastases (M) TNM system, similar to other types of carcinomas. The World Health Organization includes different parameters for each anatomical site [11, 12]. The management of GEP-NENs requires a multidisciplinary approach. Surgery is the only therapy with potential complete cure [14]. Medical therapy of inoperable or metastasized NENs includes multimodality options such as long-acting somatostatin analogs, $\alpha$-interferon, systemic chemotherapy and ablation therapy $[15,16]$. Chemotherapy is recommended for patients with metastatic disease or poorly differentiated tumor. There is no established regimen due to heterogeneity of the studies, including various grades, sites and inconsistent 
Kuriry and Swied: Large-Cell Neuroendocrine Carcinoma of the Esophagus: A Case from Saudi Arabia

response criteria [16]. Novel therapies like mammalian target of rapamycin (mTOR), tyrosine kinase and angiogenesis inhibitors have showing promising results in clinical trials [8].

We herein report a case of esophageal large-cell NECs and review the published literature on this rare disease.

\section{Case Report}

A 66-year-old Saudi female housewife with a background of diabetes, hypertension and hypothyroidism was seen initially by a gastroenterologist. She was suffering from progressive difficulty in swallowing, mainly of solid food, with a feeling of food stuck in the middle of her chest for more than 6 months. She denied any painful swallowing, oral thrush, chocking attacks, food impaction or nasal regurgitation. There was no heartburn, nausea or vomiting. She denied any abdominal pain, distension, rectal bleeding or change in bowel habits. She had lost about $3 \mathrm{~kg}$ from a baseline weight of $68 \mathrm{~kg}$ despite normal appetite. She denied any history of smoking, alcohol consumption or illicit drug use. Her history was unremarkable for esophageal disease, tuberculosis contact, neck swelling or radiation exposure. There was no family history of gastrointestinal malignancy or similar illness. No new medication had recently been added. System review was unremarkable. The patient underwent esophagogastroduodenoscopy (EGD) which revealed a small esophageal nodule in an otherwise normal esophagus (fig. 1a), and nodule biopsy was consistent with papilloma. Despite of the prescription of a proton pump inhibitor (esomeprazole), her symptoms worsen so that she was referred to our institution in December 2014 for further evaluation and endoscopic ultrasound.

Upon evaluation she was well, not pale or jaundiced, her weight was $64.8 \mathrm{~kg}$ and her body mass index was 26.6. There was no palpable neck mass or cervical lymph node. No oral ulceration or thrush was seen on oral examination. The abdomen was soft and non-tender, and no mass or lymph node was observed. Chest and cardiovascular examination were unremarkable. Her complete blood count showed white blood cell $16.9 \times 10^{9} /$, hemoglobin $11.8 \mathrm{~g} / \mathrm{dl}$ and platelets $306 \times 10 \% / \mathrm{l}$. Serum electrolytes, renal and liver function tests were within normal limits. C-reactive protein was $<3.5 \mathrm{mg} / \mathrm{l}$ and chest X-ray was normal.

Repeat EGD and endoscopic ultrasound examination revealed an ulcerated esophageal mass $4 \mathrm{~cm}$ in diameter 23-27 cm from the incisor line (fig. 1b, c). It was shown as a hypoechoic mass at the level of the third submucosal layer with no local lymph node or vascular infiltration (fig. 2). A computed tomography scan showed an eccentric $3.2 \times 2.0 \mathrm{~cm}$ mass in the lower esophagus, inseparable from the esophageal wall. Positron emission tomography/computed tomography revealed a hypermetabolic esophageal tumor with left cervical lymph node and midsacrum and right acetabulum metastasis (fig. 3). Histopathological examination of the deep biopsies concluded that the mass was a NEC of the large-cell type in view of irregular strands of large polygonal cells with an intermediate amount of pale oncophilic cytoplasm. The nuclei had occasional molding of salt and paper chromatin and visible nucleoli with extensive nuclear crushing artifact and immunohistochemical evidence of neuroendocrine differentiation. Tumor cells were reactive with synaptophysin and chromogranin A stain. The Ki-67 labeling index was 75\% (fig. 4). The patient was therefore staged as metastatic high-grade large-cell neuroendocrine tumor of the esophagus.

Chemotherapy was initiated by the oncologist and she received three cycles of cisplatin $90 \mathrm{mg} / \mathrm{m}^{2}$ in divided doses over 3 days and etoposide $100 \mathrm{mg} / \mathrm{m}^{2}$ per day on days $1-3 \mathrm{of}$ each treatment cycle. 
Kuriry and Swied: Large-Cell Neuroendocrine Carcinoma of the Esophagus: A Case from Saudi Arabia

\section{Discussion}

Large-cell NEC of the esophagus is exceedingly rare; few cases have been reported in the literature [17-19]. This is probably because the neuroendocrine system is not well developed in the esophagus. The incidence of esophageal NENs ranges between 0.05 and $2.4 \%$ in most of the recent studies [20-22]. The literature clearly shows that NENs in this anatomical location occur more frequently in males in the sixth and seventh decades of life, with a male:female ratio of 4:1 [18, 21, 22]. Similar to other esophageal tumors, patients usually present with vague symptoms, including constitutional symptoms, weight loss, chest pain or pressure and odynophagia. By far dysphagia is the most common presenting symptom and carcinoid symptoms are rare $[18,21]$. From endoscopic findings, esophageal NENs are typically single lesions and commonly develop in the lower third of the esophagus. This is because neuroendocrine cells are mainly distributed in mucosal glands of the distal esophagus $[18,23,24]$.

Among the categories of NENs, NEC is a poorly differentiated, high-grade malignant neoplasm composed of small or large cells, sometimes with organoid features resembling well-differentiated neuroendocrine tumors, diffusely expressing the general markers of neuroendocrine differentiation (diffuse expression of synaptophysin, faint or focal staining for chromogranin A), with marked nuclear atypia, multifocal necrosis and a high number of mitoses ( $>20$ per 10 high-power fields); high grade (G3) is defined according to proliferation fraction and histology (table 1) [25]. Large-cell tumors all consist of cells with solid nests or acinar structures, a low nuclear/cytoplasm ratio, often abundant cytoplasm, many mitoses, focal areas of necrosis, vesicular chromatin and visible nucleoli [26, 27].

For practical purposes, esophageal NECs can be staged according to the TNM/staging classification for esophageal carcinomas [28, 29]. In contrast to other gastrointestinal sites, there is no proposed TNM/staging classification for NECs of the esophagus. The relative rarity of esophageal NECs may account for this. There are no data on prognostic factors associated with esophageal NECs. However, proliferative activity, assessed by mitotic count or Ki-67 immunostaining, was described as a significant prognostic factor in a previous study [30]. There have been a few randomized, prospective and controlled therapeutic trials published thus far. Unfortunately, in those trials several tumor entities (e.g. tumors arising from the stomach, pancreas and colon) were all included. Moreover, there are not specific recommendations, given that doses and schedules were different in the various studies. Therefore, it is difficult to establish a specific treatment algorithm for esophageal NECs.

\section{Conclusion}

High-grade NECs of the esophagus are rare tumors exhibiting an overall aggressive behavior, and their prognosis is dismal. The majority are locally advanced or metastatic at presentation and are rarely associated with secretory hormonal syndromes. Treatment regimens are extrapolated from more robust data published on pulmonary high-grade NECs.

\section{Statement of Ethics}

Informed consent was obtained from the present patient. 
Kuriry and Swied: Large-Cell Neuroendocrine Carcinoma of the Esophagus: A Case from Saudi Arabia

\section{References}

1 Pearse AG: The cytochemistry and ultrastructure of polypeptide hormone-producing cells of the APUD series and the embryologic, physiologic and pathologic implications of the concept. J Histochem Cytochem 1969;17:303-313.

-2 Barakat MT, Meeran K, Bloom SR: Neuroendocrine tumours. Endocr Relat Cancer 2004;11:1-18.

3 Modlin IM, Champaneria MC, Bornschein J, Kidd M: Evolution of the diffuse neuroendocrine system - clear cells and cloudy origins. Neuroendocrinology 2006;84:69-82.

4 Lawrence B, Gustafsson BI, Chan A, Svejda B, Kidd M, Modlin IM: The epidemiology of gastroenteropancreatic neuroendocrine tumors. Endocrinol Metab Clin North Am 2011;40:1-18, vii.

-5 Starker LF, Carling T: Molecular genetics of gastroenteropancreatic neuroendocrine tumors. Curr Opin Oncol 2009;21:29-33.

6 Anlauf M, Garbrecht N, Bauersfeld J, Schmitt A, Henopp T, Komminoth P, Heitz PU, Perren A, Klöppel G: Hereditary neuroendocrine tumors of the gastroenteropancreatic system. Virchows Arch 2007;451 (suppl 1):S29-S38.

7 Tomassetti P, Migliori M, Lalli S, Campana D, Tomassetti V, Corinaldesi R: Epidemiology, clinical features and diagnosis of gastroenteropancreatic endocrine tumours. Ann Oncol 2001;12(suppl 2):S95-S99.

-8 Lawrence B, Gustafsson BI, Kidd M, Pavel M, Svejda B, Modlin IM: The clinical relevance of chromogranin A as a biomarker for gastroenteropancreatic neuroendocrine tumors. Endocrinol Metab Clin North Am 2011;40:111-134, viii.

-9 Díez M, Teulé A, Salazar R: Gastroenteropancreatic neuroendocrine tumors: diagnosis and treatment. Ann Gastroenterol 2013;26:29-36.

$\checkmark 10$ Bushnell DL, Baum RP: Standard imaging techniques for neuroendocrine tumors. Endocrinol Metab Clin North Am 2011;40:153-162, ix.

11 Klimstra DS, Modlin IR, Coppola D, Lloyd RV, Suster S: The pathologic classification of neuroendocrine tumors: a review of nomenclature, grading, and staging systems. Pancreas 2010;39:707-712.

12 Rindi G, Arnold R, Bosman FT, Capella C, Kilmstra DS, Klöppel G, Komminoth P, Solcia E: Nomenclature and classification of neuroendocrine neoplasms of the digestive system; in Bosman FT, Carneiro F, Hruban RH, Theise ND (eds): WHO Classification of Tumours of the Digestive System, ed 4. Lyon, IARC Press, 2010, pp 13-14.

13 Klöppel G: Classification and pathology of gastroenteropancreatic neuroendocrine neoplasms. Endocr Relat Cancer 2011;18(suppl 1):S1-S16.

14 Plöckinger U, Rindi G, Arnold R, Eriksson B, Krenning EP, de Herder WW, Goede A, Caplin M, Oberg K, Reubi JC, Nilsson O, Delle Fave G, Ruszniewski P, Ahlman H, Wiedenmann B; European Neuroendocrine Tumour Society: Guidelines for the diagnosis and treatment of neuroendocrine gastrointestinal tumours. A consensus statement on behalf of the European Neuroendocrine Tumour Society (ENETS). Neuroendocrinology 2004;80:394-424.

15 Kwekkeboom DJ, de Herder WW, Krenning EP: Somatostatin receptor-targeted radionuclide therapy in patients with gastroenteropancreatic neuroendocrine tumors. Endocrinol Metab Clin North Am 2011;40: 173-185, ix.

16 Joseph S, Wang YZ, Boudreaux JP, Anthony LB, Campeau R, Raines D, O’Dorisio T, Go VL, Vinik AI, Cundiff J, Woltering EA: Neuroendocrine tumors: current recommendations for diagnosis and surgical management. Endocrinol Metab Clin North Am 2011;40:205-231, x.

17 Hoang MP, Hobbs CM, Sobin LH, Albores-Saavedra J: Carcinoid tumor of the esophagus: a clinicopathologic study of four cases. Am J Surg Pathol 2002;26:517-522.

18 Huang Q, Wu H, Nie L, Shi J, Lebenthal A, Chen J, Sun Q, Yang J, Huang L, Ye Q: Primary high-grade neuroendocrine carcinoma of the esophagus: a clinicopathologic and immunohistochemical study of 42 resection cases. Am J Surg Pathol 2013;37:467-483.

19 Okamoto H, Fujishima F, Kasajima A, Miyata G, Onodera K, Kamei T, Takeyama D, Zuguchi M, Satomi S, Sasano H: A large cell neuroendocrine carcinoma of the esophagus. Jpn J Gastroenterol Surg 2012;45: 914-922. Modlin IM, Sandor A: An analysis of 8305 cases of carcinoid tumors. Cancer 1997;79:813-829. Lee CG, Lim YJ, Park SJ, Jang BI, Choi SR, Kim JK, Kim YT, Cho JY, Yang CH, Chun HJ, Song SY; Neuroendocrine tumor study group: The clinical features and treatment modality of esophageal neuroendocrine tumors: a multicenter study in Korea. BMC Cancer 2014;14:569.

22 Estrozi B, Bacchi CE: Neuroendocrine tumors involving the gastroenteropancreatic tract: a clinicopathological evaluation of 773 cases. Clinics (Sao Paulo) 2011;66:1671-1675.

23 Attar BM, Levendoglu H, Rhee H: Small cell carcinoma of the esophagus. Report of three cases and review of the literature. Dig Dis Sci 1990;35:145-152.

24 Bennouna J, Bardet E, Deguiral P, Douillard JY: Small cell carcinoma of the esophagus: analysis of 10 cases and review of the published data. Am J Clin Oncol 2000;23:455-459.

25 Yang Z, Tang LH, Klimstra DS: Gastroenteropancreatic neuroendocrine neoplasms: historical context and current issues. Semin Diagn Pathol 2103;30:186-196. 
Kuriry and Swied: Large-Cell Neuroendocrine Carcinoma of the Esophagus: A Case from Saudi Arabia

26 Hamilton SR, Aaltonen LA (eds): World Health Organization Classification of Tumours. Pathology and Genetics of Tumours of the Digestive System. Lyon, IARC Press, 2000.

27 Solcia E, Klöppel G, Sobin LH: Histological Typing of Endocrine Tumours, ed 2. New York, Springer, 2000.

28 Sobin LH, Gospodarowicz MK, Wittekind C (eds): TNM Classification of Malignant Tumours, ed 7. Weinheim, Wiley, 2009.

29 Edge S, Byrd DR, Compton CC, Fritz AG, Greene FL, Trotti A (eds): AJCC Cancer Staging Manual, ed 7. New York, Springer, 2009.

-30 Fricker J: Survival prediction with neuroendocrine differentiation? Lancet Oncol 2006; 7:891.

Table 1. ENETS/WHO nomenclature and classification of GEP-NENs [12]

\begin{tabular}{|c|c|c|c|}
\hline & $\begin{array}{l}\text { Well-differentiated } \\
\text { (low-grade, G1) }\end{array}$ & $\begin{array}{l}\text { Well-differentiated } \\
\text { (intermediate-grade, G2) }\end{array}$ & $\begin{array}{l}\text { Poorly differentiated } \\
\text { (high-grade, G3) } \\
\text { small, large-cell }\end{array}$ \\
\hline Appearance & $\begin{array}{l}\text { monomorphic population } \\
\text { of small, round cells }\end{array}$ & $*$ & cellular pleomorphism \\
\hline Mitotic rate & $<2$ & $2-20$ & $>20$ \\
\hline Ki-67 index ${ }^{1}$ & $\leq 2 \%$ & $3-20 \%$ & $>20 \%$ \\
\hline Necrosis & absent & $*$ & present \\
\hline Prognosis & prolonged survival & intermediate & poor \\
\hline
\end{tabular}

${ }^{1}$ Applies only to the WHO and the European Neuroendocrine Tumor Society (ENETS) classification of GEP-NENs. * Not well defined in the medical literature.

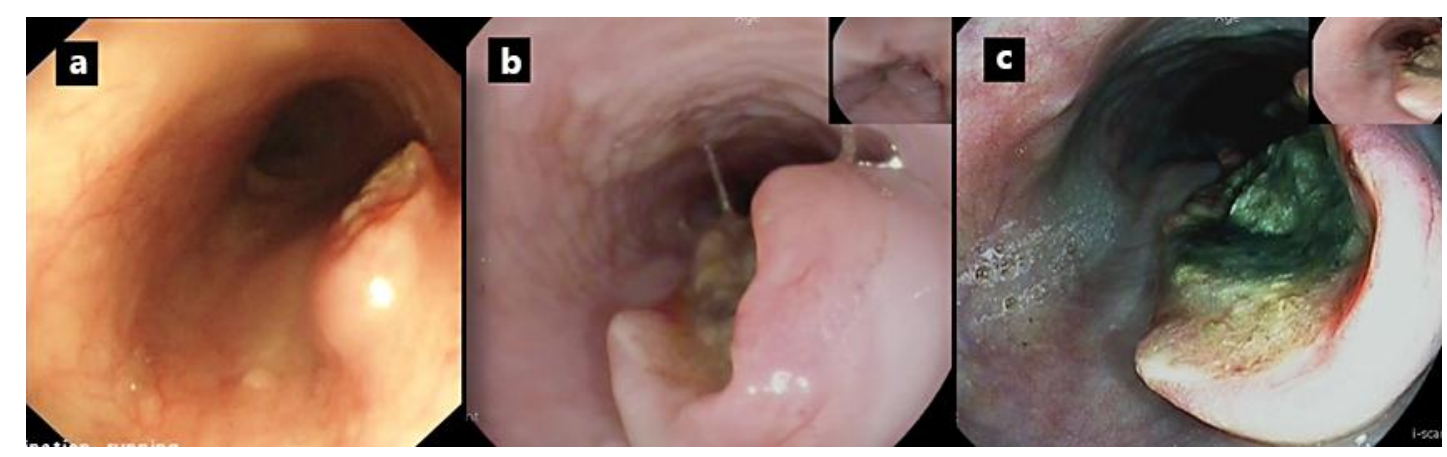

Fig. 1. a Endoscopic view of the esophagus showing a small esophageal nodule $23 \mathrm{~cm}$ from the incisor line. b, c On repeat EGD, an ulcerated esophageal mass measuring around $4 \mathrm{~cm}$ was seen at the previous nodule site. 


\begin{tabular}{|c|c|c|}
\hline \multirow{3}{*}{$\begin{array}{l}\text { Case Reports in } \\
\text { Gastroenterology }\end{array}$} & \multirow{2}{*}{\multicolumn{2}{|c|}{ Case Rep Gastroenterol 2015;9:327-334 }} \\
\hline & & \\
\hline & DOI: $10.1159 / 000441381$ & $\begin{array}{l}\text { (c) } 2015 \text { The Author(s). Published by S. Karger AG, Basel } \\
\text { www.karger.com/crg }\end{array}$ \\
\hline
\end{tabular}

Kuriry and Swied: Large-Cell Neuroendocrine Carcinoma of the Esophagus: A Case from Saudi Arabia

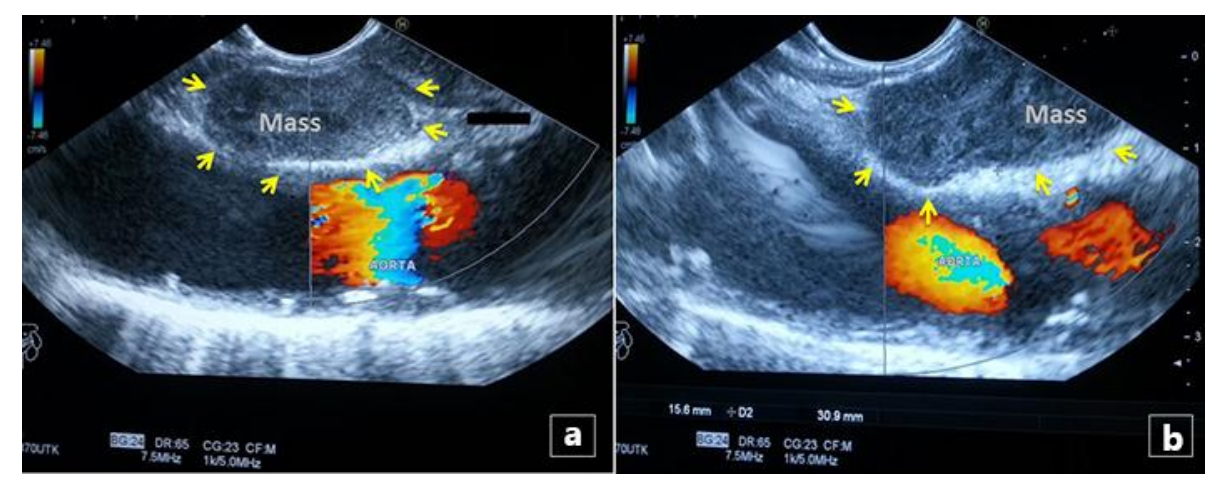

Fig. 2. a, b Endoscopic ultrasound showed a hypoechoic mass (arrows) at the level of the third submucosal layer without invasion of adjacent structures.

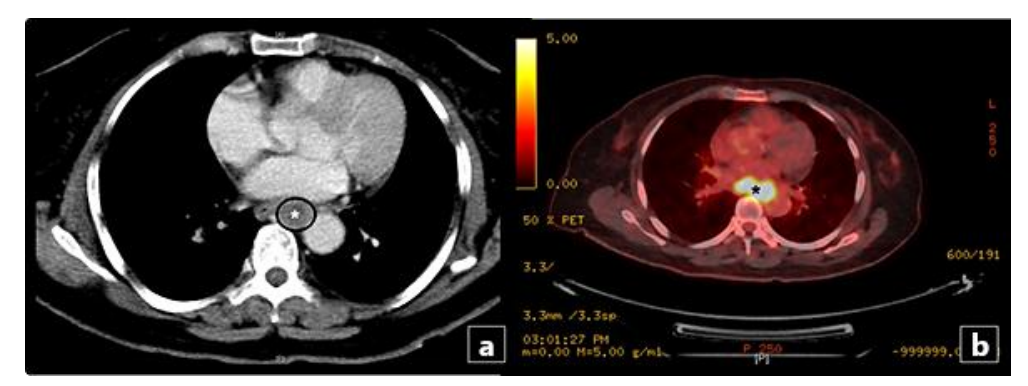

Fig. 3. a Axial contrast-enhanced computed tomography showed an eccentric $3.2 \times 2.0 \mathrm{~cm}$ mass (asterisk) in the lower esophagus, inseparable from the esophageal wall. b Positron emission tomography-computed tomography demonstrated a hypermetabolic esophageal mass (asterisk). 


\begin{tabular}{rl|l} 
Case Reports in & & \\
\cline { 2 - 3 } Gastroenterology & Case Rep Gastroenterol 2015;9:327-334 \\
\cline { 2 - 3 } & DOI: 10.1159/000441381 & $\begin{array}{l}\text { ○ 2015 The Author(s). Published by S. Karger AG, Basel } \\
\text { www.karger.com/crg }\end{array}$ \\
\hline
\end{tabular}

Kuriry and Swied: Large-Cell Neuroendocrine Carcinoma of the Esophagus: A Case from Saudi Arabia
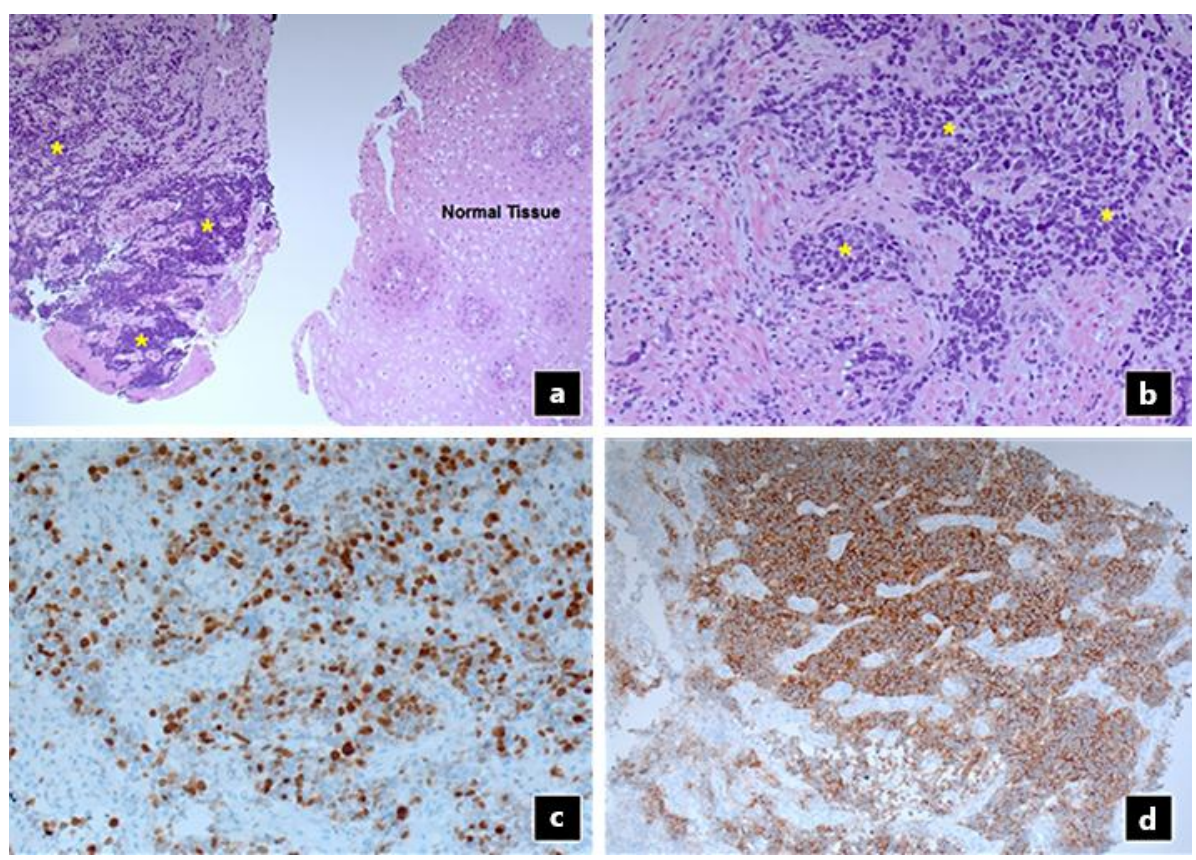

Fig. 4. Histopathological findings of the esophageal mass. a, b Low-power sections revealed large polygonal cells with an intermediate amount of pale oncophilic cytoplasm with extensive nuclear crushing artifact. c, d Immunohistochemical staining showing tumor cells with a positive reactivity for synaptophysin stain (c) and a Ki-67 index of $75 \%$ (d). 